\title{
Molecular sexing and intersexual differences in the morphometry of the Hangnest Tody-Tyrant Hemitriccus nidipendulus (Passeriformes: Rhynchocyclidae)
}

\author{
Reinaldo T. Medeiros $\left(\mathbb{1}^{1}\right.$, Flávia G. Chaves $\mathbb{D}^{2,3}$, Maurício B. Vecchi ${ }^{4}$, \\ Denise M. Nogueira $\mathbb{D}^{5}$, Maria Alice S. Alves $\mathbb{B}^{4}$
}

\begin{abstract}
${ }^{1}$ Graduação em Ciências Biológicas, Universidade Veiga de Almeida. Rua Ibituruna 108, 20271-020 Rio de Janeiro, RJ, Brazil. ${ }^{2}$ Programa de Pós-graduação em Ecologia e Evolução, Instituto de Biologia Roberto Alcantara Gomes, Universidade do Estado do Rio de Janeiro. Rua São Francisco Xavier 524, 20550-011 Rio de Janeiro, RJ, Brazil. ${ }^{3}$ Instituto Nacional da Mata Atlântica. Avenida José Ruschi 4, 29650-000 Santa Teresa, ES, Brazil. ${ }^{4}$ Departamento de Ecologia, Instituto de Biologia Roberto Alcantara Gomes, Universidade do Estado do Rio de Janeiro. Rua São Francisco Xavier 524, 20550-011 Rio de Janeiro, RJ, Brazil.

${ }^{5}$ Departamento de Genética, Instituto de Ciências Biológicas e da Saúde, Universidade Federal Rural do Rio de Janeiro. Rodovia BR 465, km 7, 23897-000 Seropédica, RJ, Brazil.

Corresponding Author. Maria Alice S. Alves (masaalves19@gmail.com)
\end{abstract}

http://zoobank.org/0221CCFF-D229-4189-8016-1491B4A6D322

\begin{abstract}
Variation in the morphometry of individuals in a population may result from natural or sexual selection. In the present study we investigated morphometric differences between males and females of a bird species endemic to the Brazilian Atlantic Forest, the Hangnest Tody-Tyrant, Hemitriccus nidipendulus (Wied, 1831), with no apparent sexual dimorphism. All individuals $(n=56)$ were sexed by PCR amplification of the intronic fragments of the CHDZ/CHDW alleles obtained from blood samples, and 12 morphometric measurements were recorded. The molecular configuration was similar to that described for other species of Passeriformes, with males presenting a single band of approximately 360 base pairs (bp), and females with two bands of 360 and 400 bp. Males had significantly larger tarsi and wings than the females, while the females had two larger beak measurements. This indicates that differential selection pressures may be modeling the morphometry of the Hangnest Tody-Tyrant. In the males, larger tarsi and wings may be beneficial for the exploration of the habitat or the acquisition of potential mates, while females with larger beaks may be able to exploit larger food items and forage more efficiently. However, these hypotheses need to be tested empirically in future studies.
\end{abstract}

KEY WORDS. Atlantic Forest, gender differences, molecular sexing, restinga, sexual monomorphism.

\section{INTRODUCTION}

Birds may exhibit sexual dimorphism in their plumage, morphometry or behavior (Fuchs and Montalti 2016), reflecting the influence of natural selection (Selander 1966) and/or sexual selection (Andersson 1994, Székely et al. 2004). In the presence of intersexual differences in size and shape, the occupancy of different niches within a given habitat is possible. This may lead each sex to exploit a different part of the habitat, resulting in spatial segregation. In this context, morphometric traits may also vary systematically between juveniles and adults, and between males and females (Senay et al. 2017).

Although about half of all bird species are dimorphic, their sex differences become apparent only in their adult stage (Griffiths et al. 1998). Considering that, a fundamental problem for the evaluation of the role of sexual dimorphism in the ecology of these organisms are the difficulties in assigning immature individuals to the correct sex. One of the most reliable and widely-used sexing methods is the amplification by Polymerase Chain Reaction (PCR) of an intronic segment of the chromo-helicase DNA binding gene (CHD), which is linked to the bird sex chromosomes ZZ/ZW (Griffiths et al. 1998). The differences in the length of the two alleles can be used to identify the individual's gender. Females have two distinct fragments $(C H D Z / C H D W)$, whereas the males have only one (CHDZ). In most bird species, the $C H D W$ fragment, found only in the female, has the longest amplicon, although in some species, such as the Rock Pigeon, Columba livia Gmelin, 1789 (Columbidae), CHDZ is the longest amplicon (Griffiths 
et al. 1998). The size and sequence of the amplified fragments vary among different species, but are normally homogeneous in individuals of the same species, although some intraspecific polymorphisms have been described (Dawson et al. 2001).

The sequences of these intronic regions have been described in only a few Brazilian bird species up to now. For example, the CHDZ/CHDW intronic fragments of only one of the 67 species of Rhynchocyclidae Berlepsch, 1907, the Ochre-bellied Flycatcher Mionectes oleagineus (Lichtenstein, 1823), have been described (Caio S. Ferreira unpublished data). In this species, the CHDZ fragment has approximately 360 base pairs (bp) and the CHDW fragment, $390 \mathrm{bp}$. The rhynchocyclid genus Hemitriccus Cabanis \& Heine, 1859 has 22 species (Piacentini et al. 2015) and, given its phylogenetic proximity to Mionectes, a similar configuration of the $\mathrm{CHDZ} / \mathrm{CHDW}$ intronic fragments would be expected in Hemitriccus, including the Hangnest Tody-Tyrant, Hemitriccus nidipendulus (Wied, 1831).

Rhynchocyclidae comprises exclusively Neotropical species, which are often classified as a subfamily of the Tyrannidae Vigors, 1825. Based on an extensive analysis of the DNA sequence data of the tyrannid clade, however, Tello et al. (2009) proposed that a group of rhynchocycline flycatchers (including Hemitriccus) should be considered a distinct family, an arrangement that has been upheld since 2010 by the Brazilian Ornithological Records Committee (see Piacentini et al. 2015 for the current checklist of the birds of Brazil). With no apparent sexual dimorphism, the Hangnest Tody-Tyrant is an insectivorous species endemic to the Brazilian Atlantic Forest (Bencke et al. 2006, Vale et al. 2018), where it occurs in coastal "restingas" and humid evergreen forests, particularly in dense and secondary habitats (Sick 1997, Clock 2018). The analysis of morphometric differences between the sexes in phylogenetically close species has identified variation in body dimensions, such as the wing and tail, with males showing larger measurements than females in both the Rhynchocyclidae (Botero-Delgadillo 2010) and Tyrannidae (Cueto et al. 2015). Differences in beak dimensions have also been found in some rhynchocyclids (Botero-Delgadillo 2010).

In the present study, the $C H D Z / C H D W$ gene fragments of the Hangnest Tody-Tyrant were investigated to confirm the sex of individuals and to evaluate potential morphometric measurements that could be used to reliably identify the sex of individuals without the need for molecular analyses, and in particular, parameters that can be applied to other species of the same family. As males are typically larger than females, and have larger beaks, as observed in other rhynchocyclid species (Botero-Delgadillo 2010) and most other birds (Székely et al. 2007), we hypothesized that a similar pattern may be found in the Hangnest Tody-Tyrant.

\section{MATERIAL AND METHODS}

Individuals were sampled in the restinga habitat (sandy coastal plain associated with the Atlantic Forest) of the Massambaba region in the state of Rio de Janeiro, Brazil, which is considered an Important Bird Area (IBA RJ08: "Restinga de Massambaba and Ilha de Cabo Frio") of the Brazilian Atlantic Forest domain, due to the presence of the local endemic, Restinga Antwren, Formicivora littoralis Gonzaga \& Pacheco, 1990 (Bencke et al. 2006). In the present study, we sampled three locations in the Costa do Sol State Park: Ponta das Coroinhas (22 $55^{\prime} 3^{\prime \prime} S$; $42^{\circ} 16^{\prime} 34^{\prime \prime} \mathrm{W}$ ) and Brejo do Espinho (22 $\left.55^{\prime} 40^{\prime \prime} \mathrm{S} ; 42^{\circ} 16^{\prime} 12^{\prime \prime} \mathrm{W}\right)$, in the municipality of Arraial do Cabo, and Praia do Vargas $\left(22^{\circ} 56^{\prime} 14^{\prime \prime} \mathrm{S} ; 42^{\circ} 17^{\prime} 30^{\prime \prime} \mathrm{W}\right)$, in the municipality of Araruama. The distance between sample sites ranged from 2 to $6 \mathrm{~km}$, and all the sites are covered with shrubby and dense restinga vegetation.

The Hangnest Tody-Tyrant individuals were captured regularly using mist-nets ( $12 \times 2.5 \mathrm{~m}, 36 \mathrm{~mm}$ mesh) between October 2011 and September 2014. The nets were set randomly along trails and in natural gaps in the vegetation in the morning (6:00-10:00 am) and afternoon (3:00-6:00 pm). We banded each captured individual with a metal ring (CEMAVE license number: 14210), measured it, and collected 10-50 $\mu$ l of blood from the tarsal vein with a disposable needle $(13 \times 4.5 \mathrm{~mm})$. Using a Pesola dynamometer (precision of $0.5 \mathrm{~g}$ ), a ruler (precision $1 \mathrm{~mm}$ ), and a caliper (precision $0.1 \mathrm{~mm}$ ), one of the authors (RTM) took the following morphometric measurements: weight, total length, tail length, wing length, nostril-beak tip, exposed culmen, beak depth at the nostril and the base, beak width at the nostril and the base, tarsus length and length of the head to beak tip. Each individual was released near the site of its capture, usually less than one hour after being processed. The present study was conducted under the approval of Institutional Ethic Commitee at UERJ (CEUA - Comissão de Ética no Uso de Animais) \#065/2018.

The DNA was extracted using the salting-out method (FitzSimmons et al. 1995). All individuals were sexed by amplifying the highly conserved ZW chromosome-linked CHD gene, using the primers P2 and P8 (Griffiths et al. 1998). The CHDW and CHDZ alleles were amplified by PCR in a $10 \mu \mathrm{l}$ reaction volume containing $10 \mathrm{ng}$ of DNA, $1 \mathrm{X}$ buffer (75 mM Tris-HCl pH 9.0, 20 $\mathrm{mM}(\mathrm{NH} 4) 2 \mathrm{SO}_{4}, 0.01 \%$ Tween 20), $0.25 \mathrm{U}$ Taq DNA polymerase (Thermoprime plus, Advanced Biotechnologies), $200 \mu \mathrm{M}$ of dNTPs (Gibco), $2 \mathrm{mM}$ of $\mathrm{MgCl}_{2}$ and $1 \mu \mathrm{M}$ of each primer, P2 (5'TCT GCA TCG CTA AAT CCT TT- 3') and P8 (5'-CTC CCA AGG ATG AGR AAY TG-3'). The alleles were amplified in a Hybaid Touchdown thermal cycler (Thermo Hybaid, Ashford, Middlesex, UK). The PCR protocol used here was an initial denaturation at $94{ }^{\circ} \mathrm{C}$ for $2 \mathrm{~min}$, followed by 40 cycles of $94^{\circ} \mathrm{C}$ for $45 \mathrm{~s}, 50{ }^{\circ} \mathrm{C}$ for $45 \mathrm{~s}$ and $72{ }^{\circ} \mathrm{C}$ for $45 \mathrm{~s}$, with a final extension of $5 \mathrm{~min}$ at $72{ }^{\circ} \mathrm{C}$. PCR products were analyzed by electrophoresis in $2.5 \%$ agarose gel in $1 \mathrm{X}$ TBE buffer at $70 \mathrm{~V}$ for three hours, stained with $5 \%$ ethidium bromide solution $(10 \mathrm{mg} / \mathrm{ml})$ and visualized in a transilluminator with UV light.

Student's t test for independent samples, run in Statistica 10 , was used to compare the morphometric measurements between the two sexes, and a standard discriminant analysis was used to evaluate the proportion of individuals whose sex was identified correctly, and which variable contributed most to the 
identification of the sex of the individuals. Discriminant analysis is sensitive to sample size (Hair et al. 2005, Dechaume-Moncharmont et al. 2011), requiring a minimum of 20 individuals for each predictor variable (Hair et al. 2005), but smaller sample sizes has been used successfully in a number of studies (reviewed in Dechaume-Moncharmont et al. 2011). Therefore, we performed this test, even with the small sample size for females $(n=16)$. We used a jackknife validation, following Dechaume-Moncharmont et al. (2011), to estimate the proportion of individuals sexed correctly by the discriminant analysis. This procedure was run in the R program (R Core Team 2011).

\section{RESULTS}

Fifty-six adult Hangnest Tody-Tyrant were captured and banded. The molecular genetic analysis revealed that 40 of these individuals were males and 16 were females. The intronic CHDZ fragment had approximately $360 \mathrm{bp}$, while the $C H D W$ fragment had $400 \mathrm{bp}$ (Fig. 1). Based on this molecular analysis, we compared the morphometric traits of the two genders. Males had significantly longer wings and tarsi than females (Table 1), while larger values were recorded for the nostril-tip and beak depth of females (at the base). The discriminant analysis showed that males and females differed in their morphometry (Wilks' Lambda $=0.60, \mathrm{~F}=2.54, \mathrm{p}<0.01$ ) with tarsus length being the morphometric trait that most contributed to the differentiation of the sexes (Table 2). The jackknife cross-validation process revealed that $60 \%$ of the females (10 of 16 individuals) and $90 \%$ of the males (36 of 40 individuals) were sexed correctly based on their morphometric traits.

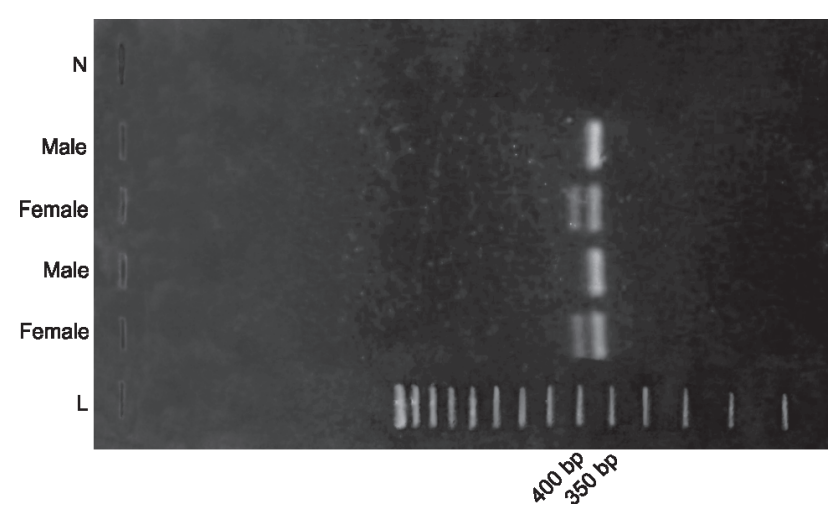

Figure 1. The DNA fragments of the intronic region of the CHDZ/ CHDW alleles of the Hangnest Tody-Tyrant individuals captured in the Costa do Sol State Park, in southeastern Brazil. The fragments were amplified by Polymerase Chain Reaction (PCR) and electrophoresed in $2.5 \%$ agarose gel. The first column on the left $(\mathrm{L})$ is a 50 bp DNA ladder, followed by the CHDZ/CHDW amplicons of the females, which present two bands $(C H D Z=\sim 360$ bp and $C H D W=$ $400 \mathrm{bp}$ ), while males had only one band (CHDZ), with the negative control $(\mathrm{N})$, consisting of only water.

\section{DISCUSSION}

The amplification of the intronic region of the CHD gene of the Hangnest Tody-Tyrant revealed that the CHDW allele is the largest amplicon, as observed in most bird species (Griffiths et al. 1998). A similar pattern has been recorded in a second rhynchocyclid, the Ochre-bellied Flycatcher (Caio S. Ferreira unpublished data), supporting that phylogenetically close species have a similar configuration of the CHDZ/CHDW alleles, when amplified with the P2/P8 primers (Griffiths et al. 1998). The male and female Hangnest Tody-Tyrant were morphometrically different, with males having larger body size parameters (tarsus and wing length), while the females had larger beaks (nostril-tip and beak height at the base). Theoretically this difference may reflect different selection pressures influencing the morphometry of each sex. In males, larger tarsi and wings can be beneficial for longer and faster flight, allowing a more efficient exploration of habitats, even though smaller wings may enhance maneuverability (Anderson and Norberg 1981), which may favor territorial defense, for example, and might be advantageous if females prefer more acrobatic males (Hakkarainen et al. 1996). It is important to note that differences in tarsal morphometry, as observed in the present study, may be associated with gender-based niche partitioning, given the importance of the tarsus in tyrannid foraging behavior (Fitzpatrick 1985). An enhanced tarsus may be beneficial for ambushing arthropods by pouncing, which would be important for an insectivorous bird such as the Hangnest Tody-Tyrant.

In the females, morphometric traits may have evolved in response to the need to avoid intraspecific competition with males for food resources. In this specific case, larger beaks may facilitate the capture of a more diverse array of arthropods by the females, in particular, larger prey. Unfortunately, this hypothesis cannot be tested empirically due to the lack of data on the diet of the Hangnest Tody-Tyrant. Selander (1966) argued that gender-based differences in size should be reflected in differences in the diets of the two sexes. However, variation in beak morphometry may also be related to mate choice and sexual selection, as observed in four subspecies of the Swamp Sparrow Melospiza georgiana (Latham, 1790), in which females mated preferentially with males that had larger beaks (Olsen et al. 2013).

Morphometric differences between males and females have been recorded in a number of other Neotropical birds, such as the Creamy-bellied Thrush, Turdus amaurochalinus Cabanis, 1850, a migrant that overwinters in the same habitat as the Hangnest Tody-Tyrant. The males of this thrush have larger wings than the females, which could allow them to fly faster and arrive first at their breeding grounds (Silva et al. 2011). In resident species, larger wing size has been recorded in male Chestnut-capped foliage-gleaner Clibanornis rectirostris (Wied, 1831) in the Serra do Cipó National Park, in the Brazilian Cerrado savanna (Faria et al. 2007), and in the male Restinga Antwren in the coastal restinga (Chaves and Alves 2013). The males of both 
Table 1. Mean, standard deviation (sd), t-test result, and corresponding probabilities of morphometric measurements (mm) and weight (g) of 56 individuals of the Hangnest Tody-Tyrant (40 males and 16 females) in Costa do Sol State Park, southeastern Brazil.

\begin{tabular}{lcccc}
\hline \multicolumn{1}{c}{ Measurements } & Males $\pm s d($ range $)$ & Females $\pm s d($ range $)$ & Student's t-test & Probability $(p)$ \\
\hline Weight & $7.90 \pm 0.68(6.5-9.7)$ & $7.58 \pm 0.55(6.5-8.5)$ & 0.71 & 0.47 \\
Total length & $90.4 \pm 2.97(85-97)$ & $89.3 \pm 3.01(83-94)$ & 0.88 & 0.38 \\
Wing length* & $45.2 \pm 1.27(43-48)$ & $44.4 \pm 1.54(41-47)$ & 2.00 & 0.04 \\
Length of tail & $39.4 \pm 1.31(35-39)$ & $38.9 \pm 0.86(33-36)$ & 0.10 & 0.91 \\
Tarsus length* & $19.0 \pm 0.55(18-19.8)$ & $18.5 \pm 0.43(17.8-19.4)$ & 3.16 & 0.002 \\
Exposed culmen & $11.2 \pm 0.51(9.9-12.3)$ & $11.4 \pm 0.52(10.2-11.9)$ & -1.06 & 0.29 \\
Nostril-tip* & $8.1 \pm 0.33(7.5-8.9)$ & $8.3 \pm 0.44(7.9-8.9)$ & -2.10 & 0.04 \\
Beak depth in nostril & $2.8 \pm 0.14(2.5-3.2)$ & $2.9 \pm 0.15(2.8-3.4)$ & -0.79 & 0.08 \\
Beak width in nostril & $3.7 \pm 0.19(3.4-4.1)$ & $3.8 \pm 0.19(3.5-4.2)$ & -2.38 & 0.02 \\
Beak height in base* & $3.1 \pm 0.13(2.8-3.4)$ & $3.2 \pm 0.21(3.0-3.9)$ & 0.02 & 0.97 \\
Beak width in base & $8.0 \pm 0.72(7.0-9.0)$ & $8.0 \pm 0.65(7.1-9.7)$ & -0.72 & 0.47 \\
Head to beak tip & $29.3 \pm 0.44(28.4-30)$ & $29.3 \pm 0.41(28.2-29.9)$ & & \\
\hline
\end{tabular}

*Significant results.

Table 2. Discriminant analysis for all morphometric measurements of the Hangnest Tody-Tyrant (Males $=40$ and females $=16$ ) captured in Costa do Sol State Park, southeastern Brazil.

\begin{tabular}{lcc}
\hline \multicolumn{1}{c}{ Measurements } & Wilk's lambda & p-level \\
\hline Weight & 0.60 & 0.96 \\
Total length & 0.62 & 0.18 \\
Wing length & 0.63 & 0.11 \\
Length of tail & 0.61 & 0.53 \\
Tarsus length* & 0.67 & 0.02 \\
Exposed culmen & 0.60 & 0.67 \\
Nostril-tip & 0.65 & 0.06 \\
Beak depth in nostril & 0.62 & 0.20 \\
Beak width in nostril & 0.61 & 0.50 \\
Beak height in base & 0.61 & 0.36 \\
Beak width in base & 0.60 & 0.92 \\
Head to beak tip & 0.60 & 0.69 \\
\hline
\end{tabular}

*Significant results.

species defend their territories to guarantee access to potential mates. We were unable to confirm the existence of territorial behavior in the Hangnest Tody-Tyrant, but when playback was used to detect the species, these birds tended to answer promptly, possibly reflecting potential territoriality (unpublished data).

Gender differences in beak morphometry have also been found for the Restinga Antwren (Chaves and Alves 2013), reflecting habitat partitioning, with males foraging higher up in the vegetation than females (Chaves et al. 2017), even though the two sexes had a similar diet. In addition to body size, male Restinga Antwren had larger beaks than females in two parameters - nostril-tip and beak width at the nostril (Chaves and Alves 2013). The Restinga Antwren occurs in the same habitat (sandy coastal plain) in which the Hangnest Tody-Tyrant was sampled in the present study. Here, the Hangnest Tody-Tyrant females had longer and deeper beaks than the males, the opposite pattern to that observed in the previous study, and in all other studies of rhynchocyclid morphometry. In the Ochre-bellied Flycatcher, for example, males were heavier and had longer bodies, wings, and tails than the females (Caio S. Ferreira unpublished data), but no significant differences in beak parameters, while males Olive-striped Flycatchers, Mionectes olivaceus Lawrence, 1868, studied in Colombia by Botero-Delgadillo (2010), had deeper beaks than the females, as well as larger wings and tails.

Although clear gender differences were observed in the morphometry of the Hangnest Tody-Tyrant, the larger beak of the females did contradict our hypothesis. Further research should focus on the diet of the species, and in particular, the possible partitioning of feeding niches between the sexes. It will also be important to investigate the morphometry of other rhynchocyclids to determine in which species the females have larger beaks than the males, and the possible ecological implications of this morphometric difference. Despite the relatively small sample size of our study, our results indicate that body size measurements can be useful for sexing the Hangnest Tody-Tyrant, given the correct classification of $90 \%$ of males. Higher confidence level can be achieved, however, by applying the P2 and P8 primers, which can provide for this species a 100\% certainty of individual sexing.

\section{ACKNOWLEDGMENTS}

We thank Luzia Bogel and Reinaldo Fortes for logistical support, and to members of the Laboratório de Ecologia de Aves - UERJ for help during fieldwork. To Stephen Ferrari for his valuable help with revising the language. We are also grateful to CEMAVE/ICMBio and INEA for research licenses (numbers 1237 and 013/2009, respectively), Conselho Nacional de Desenvolvimento Científico e Tecnológico for the fellowships granted to M.A.S.A. (CNPq processes 308792/2009-2, 305798/2014-6 and 306579/2018-9), Fundação de Amparo à Pesquisa do Estado do Rio de Janeiro (M.A.S.A. CNE processes E-26/102.837/2012, 
E-26/203191/2015 and E-26/202835/2018, F.G.C. process E-26/201.724/2015, M.B.V. process E-26/201.778/2017), and Fundação de Amparo à Pesquisa e Inovação do Espírito Santo for the current fellowship to F.G.C. (BPIG-I, INMA).

\section{LITERATURE CITED}

Andersson M (1994) Sexual selection. Princeton University Press, Princeton, 624 pp.

Anderson M, Norberg RA (1981) Evolution of reversed sexual size dimorphism and role partitioning among predatory birds, with a size scaling of flight performance. Biological Journal of Linnean Society 15: 105-130. https://doi. org/10.1111/j.1095-8312.1981.tb00752.x

Bencke GA, Maurício GN, Develey PF, Goerck JM (2006) Áreas Importantes para a Conservação das Aves no Brasil. Parte I - Estados do Domínio da Mata Atlântica. SAVE Brasil, São Paulo, 494 pp.

Botero-Delgadillo E (2010) Criterios morfométricos y cualitativos para la determinación de la edad y el sexo en Mionectes olivaceus (Tyrannidae). Hornero. 25: 9-16.

Chaves FG, Alves MAS (2013) Gender-related diet composition and morphometry of the Restinga Antwren, Formicivora littoralis (Aves: Thamnophilidae). Zoologia. 30(6): 601-606. https://doi.org/10.1590/S1984-46702013005000006

Chaves FG, Vecchi MB, Alves MAS (2017) Intersexual differences in the foraging behavior of Formicivora littoralis (Thamnophilidae), an endangered Neotropical bird. Studies on Neotropical Fauna and Environment. 52(3): 179-186. https:// doi.org/10.1080/01650521.2017.1335275

Clock B (2018) Hangnest Tody-tyrant (Hemitriccus nidipendulus). In: Del Hoyo J, Elliott A, Sargatal J, Christie DA, de Juana E (Eds) Handbook of the Birds of the World Alive. Lynx Edicions, Barcelona. https://www.hbw.com/node/57276

Cueto VR, Bravo SP, Trujillo-Arias N, Cabanne GS (2015) Sex determination by morphometry of adult White-crested Elaenia (Elaenia albiceps chilensis). Revista Brasileira de Ornitologia 23(1): 18-24.

Dawson DA, Darby S, Hunter FM, Krupa AP (2001) A critique of avian CHD-based molecular sexing protocols illustrated by a Z-chromosome polymorphism detected in Auklets. Molecular Ecology Notes 1(3): 201-204. https://doi.org/10.1046/ j.1471-8278.2001.00060.X

Dechaume-Moncharmont FX, Monceau K, Cezilly F (2011) Sexing birds using discriminant function analysis: a critical appraisal. The Auk 138(1): 78-86. https://doi.org/10.1525/auk.2011.10129

Faria LP, Carrara L, Rodrigues M (2007) Dimorfismo sexual de tamanho no fura-barreira Hylocryptus rectirostris (Wied) (Aves, Furnariidae). Revista Brasileira de Zoologia 24(1): 207-212. https://doi.org/10.1590/S0101-81752007000100027

Fitzpatrick JW (1985) Form, Foraging behavior, and adaptive radiation in the Tyrannidae. Ornithological Monographs 36: 447-470. https://doi.org/10.2307/40168298
FitzSimmons NN, Moritz C, Moore SS (1995) Conservation and dynamics of microsatellite loci over 300 million years. Molecular Biology Evolution 12(3): 432-440. https://doi. org/10.1093/oxfordjournals.molbev.a040218

Fuchs DV, Montalti D (2016) Do morphometric measurements allow sex discrimination in Mockingbirds (Mimus sp.)? All Results Journal, Biology 7(3): 34-40.

Griffiths R, Double MC, Orr K, Dawson RJG (1998) A DNA test to sex most birds. Molecular Ecology 7(8): 1071-1075. https://doi.org/10.1046/j.1365-294x.1998.00389.x

Hair JF, Anderson RE, Tatham RL, Black WC (2005) Análise multivariada de dados. Bookman, Porto Alegre, 688 pp.

Hakkarainen H, Huhta E, Lahti K, Lundvall P, Mappes T, Tolonen P, Wiehn J (1996) A test of male mating and hunting success in the krestel: the advantages of smallness? Behavioral Ecology and Sociobiology 39(6): 375-380. https://doi. org/10.1007/s002650050303

Olsen BJ, Greenberg R, Walters JR, Fleischer RC (2013) Sexual dimorphism in a feeding apparatus is driven by mate choice and not niche partitioning. Behavioral Ecology 24(6): 13271338. https://doi.org/10.1093/beheco/art071

Piacentini VDQ, Aleixo A, Agne CE, Maurício GN, Pacheco JF, Bravo GA, Brito GRR, Naka LN, Olmos F, Posso S, Silveira LF, Betini GS, Carrano E, Franz I, Lees AC, Lima LM, Pioli D, Schunck F, Raposo FA, Bencke GA, Cohn-Haft M, Figueiredo LFA, Straube FC, Cesari E (2015) Annotated checklist of the birds of Brazil by the Brazilian Ornithological Records Committee. Revista Brasileira de Ornitologia 23(2): 91-298.

R Core Team (2011) R: a language and environment for statistical computing. Available online at: http://www.R-project. org, [Accessed on 18/12/2018]

Selander RK (1966) Sexual dimorphism and differential niche utilization in birds. The Condor 68(2): 113-151. https://doi. org/10.2307/1365712

Senay C, Harvey-Lavoie S, Macnaughton CJ, Bourque G, Boisclair D (2017) Morphological differentiation in northern pike (Esox lucius): the influence of environmental conditions and sex on body shape. Canadian Journal of Zoology 95(6): 383-391. https://doi.org/10.1139/cjz-2016-0159

Sick H (1997) Ornitologia brasileira. Nova Fronteira, Rio de Janeiro, $862 \mathrm{pp}$.

Silva KVA, Hajdu GL, Alves MAS (2011) Sex determination in Turdus amaurochalinus (Passeriformes: Muscicapidae): morphometrical analysis supported by CHD gene. Revista de Biología Tropical 59(2): 789-794.

Székely T, Freckleton RP, Reynolds JD (2004) Sexual selection explains Rensch's rule of size dimorphism in shorebirds. Proceedings of the National Academy of Sciences 101(33): 12224-12227. https://doi.org/10.1073/pnas.0404503101

Székely T, Lislevand T, Figuerola J (2007) Sexual size dimorphism in birds. In: Blanckenhorn W, Fairbairn D, Székely T (Eds). Sex, size and gender roles. Oxford University Press, Oxford, 27-37. 
Tello JG, Moylea RG, Marchesea DJ, Cracraft J (2009) Phylogeny and phylogenetic classification of the tyrant flycatchers, cotingas, manakins, and their allies (Aves: Tyrannide). Cladistics 25(5): 429-467. https://doi.org/10.1111/j.10960031.2009.00254.x

Vale MM, Tourinho L, Lorini ML, Reis HR, Figueiredo MSL (2018) Endemic birds of the Atlantic Forest: traits, conservation status, and patterns of biodiversity. Journal of Field Ornithology 89(3): 193-206. https://doi.org/10.1111/jofo.12256

Submitted: December 31, 2018

Accepted: June 15, 2019
Available online: November 1, 2019

Editorial responsibility: Luís Fábio Silveira

Author Contributions: MASA, MBV and RTM designed the experiments; RTM, MBV, FGC, and DMN conducted the experiments; RTM, FGC, MBV, MASA and DMN analyzed the data and wrote the paper.

Competing Interests: The authors have declared that no competing interests exist.

(C) 2019 Sociedade Brasileira de Zoologia. Published by Pensoft Publishers at https://zoologia.pensoft.net 